\title{
Innovative Crop Productions for Healthy Food: The Case of Chia (Salvia hispanica L.)
}

\author{
Rocco Bochicchio, Tim D. Philips, Stella Lovelli, Rosanna Labella, \\ Fernanda Galgano, Antonio Di Marisco, Michele Perniola, \\ and Mariana Amato
}

\begin{abstract}
Chia (Salvia hispanica L.) is an ancient crop from Central America which has been recently rediscovered as a source of $\omega-3$ and nutraceuticals in seeds. Besides traditional seed consumption, innovative uses of the plant seeds and leaves have been proposed based on the high protein content and the production of mucilage which lends itself to a range of applications. This chapter reviews research on the plant's genetics and breeding, quality, and uses. Agronomic studies which have only recently started worldwide are also presented along with results from case studies in Basilicata.
\end{abstract}

\section{Introduction}

There is a growing body of work about chia, Salvia hispanica L., a source of plant $\omega-3$ fatty acids and nutraceuticals, since research is targeting new and functional foods worldwide. Salvia hispanica L. belongs to the Lamiaceae family, and its center of origin is between Mexico and Guatemala (Cahill 2004). It was a staple crop in pre-Columbian Mesoamerica, but its cultivation was suppressed, and it remained a little-known species for subsequent centuries outside limited areas in Mexico and Central America. Over the past two decades, since evaluation and promotion of the crop by Gentry, Coates, and others (Gentry et al. 1990; Coates and Ayerza 1996), interest in knowledge and uses of chia has grown. Much of the knowledge acquired so far on Salvia hispanica L. is related to seed quality and genetic aspects, whereas there is a lack of scientific literature on crop management

R. Bochicchio $\bullet$ S. Lovelli $\bullet$ R. Labella $\bullet$ F. Galgano $\bullet$ A. Di Marisco $\bullet$ M. Perniola $\bullet$ M. Amato $(\bowtie)$ Scuola di Scienze Agrarie, Forestali, Alimentari ed Ambientali (SAFE), Università degli Studi della Basilicata (UNIBAS), Via Ateneo Lucano 10, 85100 Potenza, Italy

e-mail: mariana.amato@unibas.it

T.D. Philips

Department of Plant and Soil Sciences, University of Kentucky, Lexington, KY 40546-0312, USA 
Fig. 1 Seeds of Salvia hispanica $\mathrm{L}$. produced in Basilicata, Southern Italy
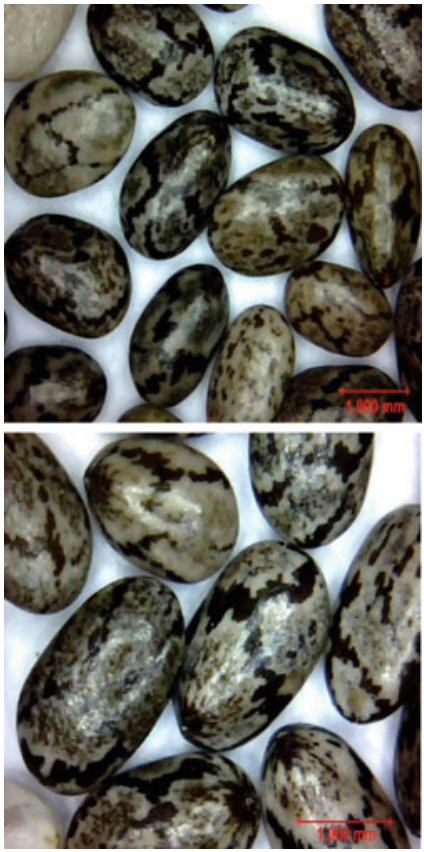

and physiological aspects as well as on agronomic characterization. Salvia hispanica L. is commonly known as "chia"; its height ranges from 60 to about $180 \mathrm{~cm}$, presents a subangular ramified stem, leaves with different degrees of pubescence, blue or white flowers, and very small indescent dry fruits commonly called seeds (Capitani et al. 2013) near ivory white to charcoal with lighter gray mottling (Fig. 1). Biometrical and physical properties of seeds have been studied by Ixtaina et al. (2008) for the purpose of better design of equipment and management related to harvest and processing. Chia is originally a short-day flowering species; the area where it can produce seeds is therefore limited to a restricted range of latitudes, but breeding is starting to produce new genotypes (Jamboonsri et al. 2012) to extend the range of this crop to other temperate areas and regions such as the Mediterranean basin. This chapter reviews findings on genetics, quality, uses and agronomy of the crop since its rediscovery in the 1990s.

\section{Genetic Diversity and Breeding}

The center of genetic and phenotypic diversity of both wild and domesticated chia populations includes the semi-temperate and temperate highlands of western Mexico and eastward spanning the trans-volcanic belt to Puebla, generally between 1,400 and 2,200 m.a.s.l. (Cahill 2004; Hernández-Gómez and Miranda-Colín 2008; 
Miranda-Colin1978). Chia cultivation traditionally occurred in this region, extending into Guatemala, and in a separate area in Honduras and Nicaragua.

Limited chia germplasm is available in gene banks, and the chia that has been collected mostly comes from domesticated rather than wild populations. Two studies have evaluated genetic diversity of chia germplasm using morphological traits and genetic markers. Cahill (2001) compared diverse germplasm sources of chia (both wild and domesticated) using 33 morphological traits as well as RAPD genetic markers. The sources of the accessions used by Cahill included collections from Howard S. Gentry, housed in the agricultural institute in Chapingo, Mexico, and lines he collected as part of his doctoral thesis work. He studied 26 quantitative and seven qualitative traits ranging from leaf and floral measurements to seed color and plant growth parameters. He found relatively little morphological differences among the accessions under study, with the exception of a few major traits related to domestication. He grouped the chia accessions into four categories: wild, cultivated, primitive domesticated, and advanced domesticated. In a second study Cahill (2004) compared genetic diversity among his collection of 38 domesticated and wild chia accessions using Random Amplified Polymorphic DNA (RAPD) markers; levels of RAPD diversity within each group, HG, showed that the highest genetic diversity was found, as expected, in wild accessions $(\mathrm{HG}=0.15)$, with less diversity in all domesticated accessions $(\mathrm{HG}=0.10)$, and a subcategory was identified within the domesticated group, the modern, commercial varieties, exhibiting the least diversity remaining $(\mathrm{HG}=0.02)$. Of the 55 polymorphic RAPD bands observed in this study, 14 were unique to wild accessions, eight bands were found only in domesticated accessions, and one band was unique to advanced domesticated accessions. These results indicate a typical pattern of a narrowing of the genetic base of the species following domestication, with a greatly diminished amount of potential genetic variation existing in current chia lines being grown in modern production areas. Cahill (2003) found a set of traits that changed during the domestication process of chia. These include closed calyces, increased plant branching, decreased pubescence, increased inflorescence length, determinacy in flowering, more pigmentation in stems, and increased plant height. Cahill also found that seed size was larger in cultivated chia than in wild germplasm and was a part of a gigantism syndrome in advanced domesticated chia lines, as well as allelopathy. In a study of inheritance of three qualitative traits in chia, Cahill and Provance (2002) found that genes for open calyces, charcoal seed color, and pigmented stems are dominant over genes for closed calyces, white seed color, and nonpigmented stems.

In another study of genetic diversity in chia, Hernández-Gómez et al. (2008) investigated variation among 22 chia germplasm sources for 23 morphological characters. Multivariate analysis of his data revealed that the chia accessions he used formed six groups, mostly related to different geographical origin. Distinct groups included chia from northern Mexico, Guerrero, Puebla, Central America (El Salvador, Guatemala and Honduras), Oaxaca, and Acatic. This study found differences between wild and cultivated chia for 19 of the 23 characters studied. 
Chia has not been the subject of many modern plant breeding efforts. Improved cultivars or populations have been developed primarily by selecting lines from mixed germplasm sources, usually landraces. In general, the domesticated chia variety "Pinta" now dominates cultivation (Cahill 2005), with a few other domesticated populations or selections being grown; for example, Sahi Alba 911, Sahi Alba 912, and Sahi Alba 914 are three white seed lines developed by mass selection. Omega-3 Chia, Inc. has plant variety protection for a variety ("Omega3") developed in Florida, obtained through mass selection from a mixed population/ landrace, likely "Pinta."

Salvia hispanica L. is a self-pollinating plant, generally setting seed at high frequency in the absence of insects (greenhouse or mesh-covered inflorescences). Hernández-Gómez et al.(2008) found much higher levels of outcrossing (over $22 \%)$ in cultivated chia, than in wild chia $(<2 \%)$ in field studies in Mexico. Cahill (2004) reported a much lower outcrossing rate of $0.24 \%$ in his field studies in California using a wild and domesticated line. In Kentucky over three growing seasons, outcrossing in white-flowered chia plants surrounded by blue-flowered chia lines was in the 3-8\% range. Many insects are attracted to chia flowers, and little outcrossing has been observed under greenhouse conditions, so it is likely that entomophily is responsible for transferring pollen rather than wind. Some South American chia growers report better chia crop yields when chia is grown in areas with healthy bee populations.

Cahill and Ehdaie (2005) investigated the inheritance of seed mass in chia. They reported a $16 \%$ increase in seed mass following one cycle of selection, but chia seed mass between wild and domesticated chia lines does not differ as much as that of other oilseed species in Lamiaceae (particularly Perilla frutescens Britt.).

Making crosses in chia is hampered by small flower size and their fragility. Many attempts at emasculation of chia flowers result in rapid floret abscission or poor success. Pollen is shed within a few hours of sunrise under greenhouse conditions. Early morning pollen transfer from plants used as males to spikes of designated female plants over several days to 2 weeks has resulted in successful crosses, with $\sim 10 \%$ of seed from a spike used in crosses being non-selfed (crossed) seed (personal observations). Making chia crosses is considerably easier when dominant phenotypic markers are available. Cahill and Provance (2002) used stem striation/pigmentation as a dominant marker. Breeding efforts at the University of Kentucky have used flower color as a dominant marker. By using whiteflowered plants as females in crosses with blue- or purple-flowered plants as males, hybrid plants can be distinguished from self-pollinated young seedlings. Blue flowering plants produce pigmented hypocotyls in the early seedling stage of growth in bright light (1-3 weeks after germination), while white-flowering selfpollinated seedlings from the attempted cross exhibit only light green hypocotyls. Alternatively, seed from attempted crosses can be grown to flowering stage, and blue-flowering plants would be actual hybrids, while white-flowering plants would be selfed (maternal parent) progeny.

Traits of interest in a traditional chia breeding program include seed yield, flowering date, rate of maturity, lodging and shattering resistance, and disease 
resistance. Hybrid cultivar production could increase chia vigor and seed yield, but would likely require the use of male sterility. The use of molecular markers and other genomics tools may be productive once more genetic information is generated for chia.

With a narrow genetic base in available germplasm, other means of finding genetic variation can be used, such as mutation breeding. Possible use of male sterility for production of hybrid chia as well as novel oil/chemical profiles and plant branching pattern and height are being investigated in populations treated with gamma radiation and chemical mutagens. Additional collections of chia germplasm from its center of origin are needed and should be available to chia breeders.

At the University of Kentucky, in field plots and in greenhouse-grown chia from numerous commercial sources, variation in leaf size and shape, stem pubescence, branching pattern, spike length, seed size, flower color, and seed color have been observed, but very little variation in photoperiod response has been found. Through mutation breeding, a number of new chia lines with a range of responses to day length have been developed (Jamboonsri et al. 2012). Most of these lines are induced to flower under day lengths between 13 and $16 \mathrm{~h}$ and a few flower under constant illumination (i.e., they are day-length insensitive). Additional breeding efforts have been focused on studying the inheritance of traits such as photoperiod response, seed color, lodging resistance, and shattering resistance. Selection for improved yield is difficult until seed shattering and lodging problems are addressed.

\section{Seed Quality}

A series of scientific papers have addressed the quality of chia seeds since the crop's rediscovery. Most of them focus on fatty acids since chia oil has the highest concentration of $\omega$-3 of all natural sources (Palma et al. 1947; Ayerza 1995; Ayerza and Coates 2011; Segura-Campos et al. 2014). Seeds are also a source of proteins, fiber, and nutraceuticals, and there is an increasing interest in those compounds in literature reports.

Also, no significant content of toxic compounds have been found in chia seeds, and there is no evidence of allergic responses (EFSA 2005, 2009) caused by the consumption of chia seeds. The omega-3 chia website (www.chiagrowers.com) reports laboratory analysis where no mycotoxins where found on tested chia samples.

The oil yield of mature chia seeds generally ranges from 29.36 to $33.50 \%$, depending on the areas of origin, climatic conditions, and on the technique used for oil extraction (Ayerza and Coates 2004, 2009a, b; Ixtaina et al. 2011; Marineli et al. 2014; Rocha Uribe et al. 2011; Silveira Coelho and de las Mercedes SalasMellado2014). Moreover, the seed's oil content tends to rise as altitudes of ecosystem in which the seeds are grown increase (Ayerza 2009). From a nutritional point of view, the concentration of fatty acids in chia seed oil ranks in the following 
order: $\alpha$-linolenic acid $>$ linoleic acid $>$ oleic acid $>$ palmitic acid $>$ stearic acid. In particular, the content of $\alpha$-linolenic acid (C18:3) is about $60 \%$ of all fatty acids present in oil.

Medical and epidemiological studies have demonstrated that $\omega-3$ fatty acids are essential nutrients and play a role in human health for the prevention of cardiovascular diseases, being antithrombotic, anti-inflammatory, antiarrhythmic, and favoring plaque stabilization. Therefore, the intake of foods containing high amounts of $\alpha$-linolenic acid is recommended. Also, an important ratio of unsaturated fats to target in the human diet is that of $\omega-6: \omega-3$ fatty acids. The ideal ratio ranges from $1: 1$ to $3: 1$, but generally in the western diet, it is much higher, even in vegetable oils, where the content of $\omega-6$ fatty acids is high. The ratio is lower than 1 in chia (Ixtaina et al. 2011; Silveira Coelho and de las Mercedes Salas-Mellado2014); therefore, chia seeds or extracted oil can be used as a means to balance the unsaturated fatty acid intake in diets.

However, genotype and environmental conditions can influence the fatty acid composition more than the total oil content in chia seeds (Ayerza 2009, 2011; Ayerza and Coates 2004, 2009a, b, 2011), and namely $\alpha$-linolenic content of chia seeds varies under differing environmental conditions and ecosystems, even in the case of a common genetic source. In general, it has been observed that as elevation of the seed production location increases, oil saturation decreases since the levels of $\alpha$-linolenic and linoleic fatty acid increase and palmitic and stearic fatty acids decrease (Ayerza and Coates 2011). The ratio of $\omega-6: \omega-3$ fatty acid ratio decreases and that of polyunsaturated fatty acid/saturated fatty acids ratio increases. Also cool temperatures can often positively affect the level of unsaturation of chia fatty acids as for other oil seed crops (Ayerza 2009; Ayerza and Coates 2004, 2011).

In addition to important fatty acid composition, chia seed and oil also represent a rich font of compounds which have beneficial effects on human health such as vitamin B (Bushway et al. 1984) and natural antioxidants such as tocopherols, phytosterols, carotenoids, and phenolic compounds, including chlorogenic acid, caffeic acid, myricetin, quercetin, and kaempferol (e.g., Reyes-Caudillo et al. 2008; Marineli et al. 2014; Amato et al. 2015), and do not represent a hazard for human health (Bresson et al. 2009).

Amato et al. (2015) report the first data on the quality of chia seeds produced in Europe, from an experiment conducted in Basilicata. They found that oil concentration from Basilicata seeds was not significantly different than that of commercially available seeds from Australia and Peru, but characterized by a higher concentration of pigments (chlorophyll and carotenoids) and $\alpha$-linolenic acid.

Chia seeds are also a source of protein and fiber: Capitani et al. (2012) report that after oil extraction, chia meal contains 19-23\% of proteins and 33.9-39.9\% of dietary fiber. Proteins in whole seeds range from 12 to $26 \%$ (Ayerza and Coates 2004, 2009a, b, 2011). Ayerza and Coates (2009a, b, 2011) report changes with environment of production, and, namely, a highly significant decrease in protein if elevation increases. Its amino acid profile is suitable for the adult diet (Weber et al. 1991). 
One of the most promising features of chia seeds is the 5-6\% content of fiber, which can be used as dietary fiber (Ayerza and Coates 2001; Reyes-Caudillo et al. 2008) but are also very interesting for industrial and pharmaceutical uses because of the high content of soluble fiber forming a highly hydrophilic mucilage. A polysaccharide with a molecular weight of $0.8-2 \times 10^{6}$ Da has been identified by Lin et al. (1994) who proposed a tentative structure as a tetrasaccharide with 4- $O$-methyl- $a$-D-glucoronopyranosyl residues occurring as branches of $b$-Dxylopyranosyl on the main chain and yielding by acid hydrolysis the monosaccharides $b$-D-xylose, $a$-D-glucose, and 4- $O$-methyl- $a$-D-glucoronic acids in the proportion 2:1:1. The fiber is localized in the fruit exocarp (Capitani et al. 2013), namely, in the first three cell layers. After contact with water, hydrated filaments of the mucilage are partially extruded out of the seed and form a transparent "capsule" which remains strongly attached to the fruit outer layers (Muñoz et al. 2012a, b).

\section{Leaf and Stem Quality}

The composition of the leaves of Salvia hispanica L. has not been the object of many studies. Ahmed et al. (1994) studied leaf oil and its composition from leaves and found 52 compounds. They identified 42 of the chemical components and found that oil composition was dominated by $\beta$-caryophyllene, globulol, $\gamma$-murolene, $\beta$-pinene, $\alpha$-humulene, germacrene- $\mathrm{B}$, and widdrol, but the relative amounts varied as a function of geographical area where the plant was grown, ranging from California to Texas to Argentina.

Peiretti and Gai (2009) reported a concentration of polyunsaturated fatty acids of $62.3-75.2 \%$ of the total fatty acids in the plant biomass, with changes between single components as a function of growing stages: they recorded a decrease of the linolenic acid content from $64.9 \%$ of the total fatty acids at early-vegetative stage to $49.9 \%$ at the budding stage, while other fatty acids increased. They also found an increase in the fibrous fractions and a strong decrease of the crude protein content after the shooting period. Another study (Peiretti 2010) showed increases in dry matter (from 8.4 to $22.4 \%$ of fresh plant weight) during the growth cycle of chia while water soluble carbohydrates increased from 8.6 to $21.3 \%$ of the dry matter. Values of soluble nitrogen in the whole plant ranged from 10.5 to $17.4 \%$.

Recently research conducted in Basilicata, Southern Italy (Amato et al. 2015), has shown secondary metabolites in leaves and provides the first report of flavonoids in chia leaves, including two uncommon compounds: acetyl vitexin and acetyl orientin which had never been reported before in the Lamiaceae family. 


\section{Uses}

Chia seeds are an important source of $\omega-3$, proteins, and antioxidants, and as such, their first use - traditional and future-is as a functional food or a nutritional supplement. Seeds may be consumed whole, after oil extraction (consuming both oil and meals), or ground as an additive to other food ingredients. They offer advantages over other available $\omega-3$ sources such as the higher content of $\omega-3$ (Ayerza and Coates 2004), the long shelf-life of whole seeds (Ahmed et al. 1994; Amato et al. 2015), and the lack of fishy flavors (Coates and Ayerza 1998). According to Ayerza and Coates (2011), keeping into account the variation in $\alpha$-linolenic fatty acid contents found in chia seeds between growing environments, an adult with an intake of 2,700 cal would need between 22.5 and $26.5 \mathrm{~g} /$ day of seeds or between 6.9 and $7.9 \mathrm{~g} /$ day of oil to reach the required daily recommendations of $\omega-3$ fatty acid. Chia can be incorporated into human diets for their protein content and composition, alone or as ingredients to produce a better source of proteins compared to other grains. Oil extracted from chia may be used as a seasoning or in cosmetics (Muñoz et al. 2013). Also, it has been used in ethnic medicine for eye infections ( $\mathrm{Lu}$ and Foo 2002; Reyes-Caudillo et al. 2008).

Chia seeds and oil can be added as ingredients to obtain functional foods, as tested in bakery products (Pizarro et al. 2013; Marineli et al. 2014; Silveira Coelho and de las Mercedes Salas-Mellado2015). Chia seeds do not contain gluten. Coeliac disease has lately become one of the most important food intolerances, and glutenfree diets are increasingly adopted, but according to Steffolani et al. (2014), they often are unbalanced and poor in fiber, iron, calcium, and rich in saturated fats. Adding chia to gluten-free flours improves their nutritional qualities and does not negatively affect organoleptic characteristics (Steffolani et al. 2014).

Therefore, the use of chia seeds is growing in food industry for the production of bread, bars, cookies, and breakfast products especially in the USA, Latin America, and Australia (Cabrera and Cerna 2014). Steffolani et al. (2014) report that whole or pre-hydrated seeds give better results compared to ground seeds for bread-making, in terms of lower specific volume and higher firmness and color. Cabrera and Cerna (2014) reported that the concentration of chia seeds affects texture and color but not the taste of bread and found the ideal amount of chia seeds is $3 \%$.

Mucopolysaccharides contained in chia fruits are useful as soluble dietary fiber and result in the production of gel surrounding the seeds when hydrated. This mucilage has been reported to be essentially composed of polysaccharides (de la Paz Salgado-Cruz et al. 2013) and to have exceptional physical properties due to the high soluble to insoluble fiber ratio (de la Paz Salgado-Cruz et al. 2013): it absorbs 27 times its own weight of water, and this amount is affected by the concentration and type of salts (Muñoz et al. 2012a, b). According to Ahmed et al. (1994) hydrated seeds are traditionally used in beverages called "agua fresca" or "chia fresca" in Mexico. 
The gel-forming phenomenon occurs in the mouth when fruits are chewed and continues inside the stomach. This gel has important effects on nutrition and health due to:

- A soothing effect on the digestive tract

- The creation of a barrier for enzymes, therefore a slow down and reduction of the breakdown of complex carbohydrates into sugars

- A satiety sensation due to the increase in the volume of the hydrates' mass (Gentry et al. 1990)

- An increase in viscosity of the bolus which then proceeds slowly in the intestinal tract, and this makes digestion more efficient and prolongs the feeling of satiety (Gentry et al. 1990; Capitani et al. 2012)

- Soluble fibers forming the gel act as probiotic and regulate blood sugar and cholesterol levels (Gentry et al. 1990; Capitani et al. 2013)

Thanks to its physical properties chia mucopolysaccharide can be used in many applications, from food to pharmaceutical industry (de la Paz Salgado-Cruz et al. 2013): as a thickening and stabilizing agent in products such as preserves, yogurt, mayonnaise, and sauces (de la Paz Salgado-Cruz et al. 2013). According to Steffolani et al. (2014) this mucilage could be used in baked products as a substitute for eggs or oil.

The use of microscopy, spectroscopy, and image analysis in a study conducted by de la Paz Salgado-Cruz et al. (2013) shows that chia mucilage can be relevant to nanotechnology research and applications since it is formed by a network of microfibrils of $18-45 \mathrm{~nm}$ width. They can therefore be considered as nanoaggregates and are likely to have several active sites on their surface. Chia mucilage is therefore suited for many high-technology uses such as the formation of nanocomposites or the controlled release of drugs.

Muñoz et al. (2012a, b) proposed the use of chia hydrocolloids to improve the properties of films and showed that films could be made from the mucilage of Salvia hispanica L. and whey protein and Dick (2014) developed biodegradable films from chia flours and mucilage. Both works show that resulting materials have low permeability and good mechanical properties. Dick (2014) also proved that chiabased biofilms have an excellent ability to absorb ultraviolet radiations and therefore can protect packaged goods. Chia mucilage has also been used as an experimental model for the study of plant-soil water relations by Kroener et al. (2014).

One technical problem in the use of chia mucilage is related to the difficult separation of the gel from fruit coats since it is firmly attached to the fruit exocarp outer cell layers (de la Paz Salgado-Cruz et al. 2013). According to Capitani et al. (2013) this phenomenon is possibly due to the association of mucilage with the columella and the cell wall, in analogy with findings on Arabidopsis. This issue is addressed by separation techniques such as the use of sonication and high pressure filtration (Marin Flores et al. 2008) or lyophilization (Capitani et al. 2013).

The high concentration of health-promoting compounds in chia seeds allows to envisage the incorporation of chia seed into animal feed to increase the linolenic acid concentration and to decrease cholesterol levels in meat and eggs (Norlaily 
et al. 2012). Ayerza and Coates $(1999,2000,2001)$ and Ayerza et al. (2002) remark that chia seeds do not show the disadvantages of other source of polyunsaturated fatty acids in the animal diet, such as fishy flavor and digestive problems.

Ayerza and Coates (2000) studied the effect of a diet including chia seeds on poultry and found a high content of polyunsaturated fatty acids and a low level of cholesterol and saturated fats in egg yolk. In a research on milk cows' diet, Ayerza and Coates (2006) found that chia seeds did not affect production or total fatty acid and cholesterol content, but they caused an increase in the percentage of $\omega-3$ fatty acids.

Meineri and Peiretti (2007) fed chia seeds to rabbits and report that a $10 \%$ of chia seeds increases the digestibility of acid detergent fiber, dry matter, organic matter, crude protein, crude fiber and gross energy. Peiretti and Meineri (2008) found significant increases in polyunsaturated fatty acids in meat as a function of the increase of chia seed ratio in the rabbit diet.

According to other authors, the seed meal after oil extraction can be a good source of protein with adequate amounts of amino acids and as such could be used as a feed supplement (Bushway et al. 1984; Weber et al. 1991)

Regarding leaves and whole plants, Peiretti and Gai (2009) reported that the quality of chia forage is a function of harvest time and is optimal before shooting. Peiretti (2010) suggests that chia has a good potential for ensiling, based on labscale experiments showing that the fermentation of chia plants is characterized by a lack of lactic acid and the presence of alcohols and volatile fatty acids. He found that isobutyric acid decreased with increasing wilting level down to null values at dry matter levels of more than $28.5 \%$ of the fresh biomass. Ethnobotanical uses of chia leaves (Cahill 2003) include leaves and vegetative parts of Salvia hispanica L. for medicinal purposes.

Ahmed et al. (1994) report that due to their oil composition, chia leaves are of potential interest for extracting flavors and fragrance; they also raise the hypothesis of use as insecticides, based on the observation that the canopy seems to deter whitefly and other insects. Subsequent research, though, has shown attacks by insects as reported below (section on disease and insect control).

\section{Agronomic Management}

Agronomic management is one of the most important aspects in cropping systems, for the success of crops, but also for the correct management of resources and energetic inputs and sustainability. Reports on agronomic management of chia are only just starting to appear in the scientific literature; most of them are based on experiments and observations conducted in the areas of origin of South and Central America and focus mainly on the response of different genotypes to growing environments in terms of phenology, yield, and quality of seeds (Ayerza and Coates 2009a, b; Ayerza 1995, 2010, 2011, 2013; Lobo Zavalia et al. 2011). Ongoing research in Basilicata, Southern Italy (Fig. 2), provides the first report of seeds 
Fig. 2 Plants of Salvia hispanica $\mathrm{L}$. in experimental fields in Basilicata, Southern Italy

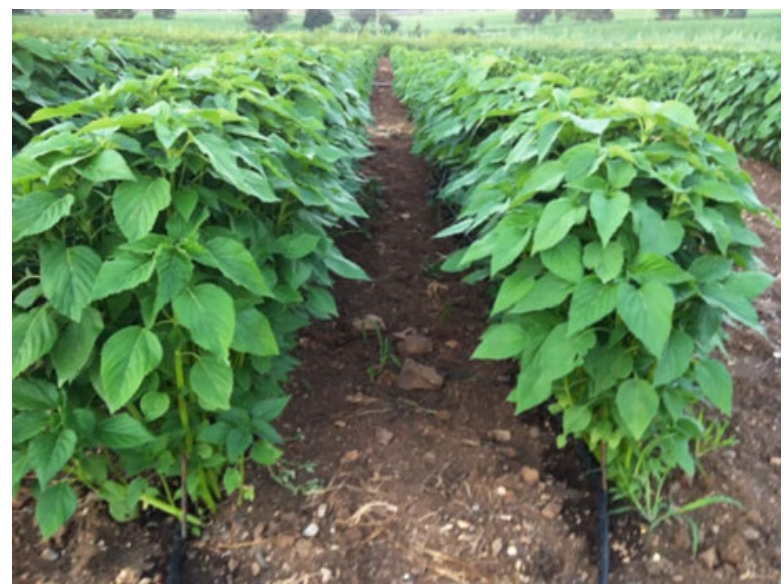

produced in Europe (Bochicchio et al. 2015) and shows that while quality is comparable to that of other traditional or new production areas (Amato et al. 2015), yields are quite low, although still in line with some of the lowproducing areas of origin. This is due to late flowering of the traditional short-day genotypes at the latitudes of South Europe and therefore to the occurrence of autumn low temperatures during grain filling. In order to fully exploit the potential for chia seed production therefore new genotypes fit for high latitudes (Jamboonsri et al. 2012) need to be used in this case. Conversely, a high potential for the production of whole fresh biomass up to $59.71 \mathrm{t} \mathrm{ha}^{-1}$ (Bochicchio et al. 2015), and for leaf production, with values of up to $11.06 \mathrm{t} \mathrm{ha}^{-1}$ of fresh and $2.02 \mathrm{t} \mathrm{ha}^{-1}$ of dry biomass (Amato et al. 2015) have been obtained with short-day genotypes due to the long duration of the vegetative stage.

Soil Chia prefers sandy, well-drained soils with moderate salinity and with a $\mathrm{pH}$ ranging from 6 to 8.5 (Yeboah et al. 2014). According to some authors this crop has low salt tolerance, and salinity can significantly reduce the seed oil yield (Heuer et al. 2002). However, chia plants adapt well to soils belonging to other texture classes provided they have good drainage and are not too wet (Muñoz et al. 2013; Lobo Zavalia et al. 2011; Baginsky et al. 2014). This crop is semi-tolerant to acid soils and drought (Muñoz et al. 2013; Baginsky et al. 2014).

Climatic Requirements Chia is a drought-resistant crop, and it has been suggested as a choice for cropping systems in semi-arid environments (Ayerza and Coates 2009a, b). This plant can grow in arid environments, and it has been proposed as an alternative to existing forage crops (Peiretti and Gai 2009). Minimum and maximum growth temperatures of this crop are $11-36{ }^{\circ} \mathrm{C}$, with an optimum range between 16 and $26{ }^{\circ} \mathrm{C}$. It is well known that this plant is very sensitive to low temperature, and it cannot produce seeds since it is killed by frost before flowers set (Ayerza and Coates 2005). The duration of the crop cycle in most cases ranges from 140 to 180 days (de Kartzow 2013; Coates and Ayerza 1996), but 
being chia sensitive to day length, the growing cycle strictly depends on the latitude where it is planted (Coates 2011).

Water While being able to grow in dry conditions (Baginsky et al. 2014), Salvia hispanica $\mathrm{L}$. benefits from rainfall events ranging from 300 to $1,000 \mathrm{~mm}$ during the whole growing season (Yeboah et al. 2014; Coates and Ayerza 1996). The optimal distribution of precipitation for this crop allows a good supply of rainfall during the first phenological phases corresponding to vegetative growth, while drier conditions are required during subsequent phases, especially seed maturation (Yeboah et al. 2014). The crop can be grown in rainfed or irrigated conditions (Coates and Ayerza 1996), but there is a lack of scientific literature on irrigation experimental trials, so there is no exact quantification of evapotranspiration of this crop.

Fertilization There is no published data from specific field experiment on fertilization of chia so far; for this reason information on this aspect is few, fragmentary, and imprecise. Chia grows well in soils with a good amount of nutrients, while a low soil nitrogen content seems to strongly reduce yield (Coates 2011). Coates and Ayerza 1996 reported amounts of nitrogen applied in field settings ranging from 21 to 45 units and Pozo Pozo (2010) reports amounts as high as 115 units. According to de Kartzow (2013), though, the recommended doses of N, $\mathrm{P}_{2} \mathrm{O}_{5}$, and $\mathrm{K}_{2} \mathrm{O}$ are 51, 43, and 60 units, respectively; the author also suggests to apply 50 units of calcium sulfate.

First results of research conducted in Basilicata, Southern Italy, has shown that after organic fertilization at sowing nitrogen topdressing has not improved yield, in connection with a higher incidence of lodging (Bochicchio et al. 2015). Amato et al. (2015) also showed that mineral fertilization increased free acidity, chlorophyll, and carotenoids in seeds, whereas it reduced $p$-anisidine value, phenols, and oxidative stability. It also seemed to affect the amount of secondary metabolites in leaves.

Sowing In South America chia is sown at a rate of $5-6 \mathrm{~kg} \mathrm{ha}^{-1}$ with a variable row spacing, the most frequent is $0.7-0.8 \mathrm{~m}$. Some studies have shown that planting date affects yield, and, namely, earlier sowing results in higher yields probably due to a longer vegetative growth period (Coates 2011). Growth and yield of chia depend also on planting method and planting density. A recent study has shown that direct planting instead of transplanting allows to achieve the best yields (Yeboah et al. 2014). As regards plant density, it has been observed that for Salvia hispanica L. the greatest variations in seed yield are related to the different planting method and plant density used in the different environment of production (Yeboah et al. 2014), and according to available data for this crop, the higher the planting density, the greater the seed yield. Results of Yeboah et al. (2014) show highest yields at a planting density of 40,000 plants $\mathrm{ha}^{-1}$ with narrow-row spacing $(0.5 \mathrm{~m} \times 0.5 \mathrm{~m})$.

A field experiment conducted at Atella in Basilicata (Southern Italy) tested the response of chia to sowing densities of 4-125 plants $\mathrm{m}^{-2}$ and first results show that 
seed yield increased with plant density (Bochicchio et al. 2015). In Kentucky we find that $2-3 \mathrm{~kg} \mathrm{ha}^{-1}$ provides better yields with less lodging.

Weed Control As for many crops, the early stages of growing are critical times for weed competition; this is especially true for chia since no herbicide has been found to be fully satisfying for weed control so far. Indeed Coates (2011) indicates that the first 45 days are very sensitive because the pressure of weed is high at a time when the growth rate of chia is very low compared with common weeds. After a good establishment of chia plants, it is possible to control weeds manually and mechanically until canopy closure (Coates 2011). There is an important need to investigate weed control in relation to plant density as highlighted in a study by Pozo Pozo (2010). In a pesticide trial conducted in Chile, Villegas et al. (2012) compared different herbicides and concluded that linuron showed the best behavior in terms of weed control and conservation of chia. In another study metribuzin and haloxyfopmethyl- $R$ were used to control weeds with good results (Pozo Pozo 2010).

Disease and Insect Control According to Pascual-Villalobos et al. (1997) chia leaves contain essential oils capable to carry a repellent action against insects and thanks to this characteristic Muñoz et al. (2013) report previous observations that this crop can be grown without pesticides or other chemical compounds. Other authors, though, observed insect attacks in particular foliage beetles able to provoke a significant insect infestation of the plant (Yeboah et al. 2014). Moreover, in Southern Italy during the crop seasons 2013 and 2014 (data not shown), insect attack on leaves by whiteflies and aphids were observed. In a recent experimental trial (Yeboah et al. 2014) Fusarium wilt infection on chia has also been observed. Moreover, recently the presence of two viruses infecting chia plants was reported, and the infection was able to determine severe disease symptoms (Celli et al. 2014). Also, Celli et al. (2014) confirmed that the virus was transmitted by whiteflies, and this confirms the presence of species of Aleyrodidae family on this crop as was observed in our field trials in Southern Italy. Such reports of the occurrence of common diseases highlight the need to assess the appropriate control methods, including pesticides useful for the pests and pathogens identified on this crop.

Harvesting Salvia hispanica L. seeds are harvested mechanically. In low input conditions, average yield is around $600 \mathrm{~kg} \mathrm{ha}^{-1}$ but can be up to $1,200 \mathrm{~kg} \mathrm{ha}^{-1}$ (Coates 2011), while in high input conditions with irrigation and fertilization, yields as high as 2,500 kg ha ${ }^{-1}$ have been shown in some experimental trials in Argentina (Coates 2011). During harvest a great problem is the scalarity of flowering and maturation: the central flower head matures and dries out while inflorescences on side branches are still green. Waiting until all seeds are dry can increase the risk of seed loss to rain, wind, or birds (Jamboonsri 2010).

Open Access This chapter is distributed under the terms of the Creative Commons Attribution Noncommercial License, which permits any noncommercial use, distribution, and reproduction in any medium, provided the original author(s) and source are credited. 


\section{References}

Ahmed M, Ting IP, Scora RW (1994) Leaf oil composition of Salvia hispanica L. from three geographical areas. J Essent Oil Res 6:223-228

Amato M, Caruso MC, Guzzo F, Commisso M, Bochicchio R, Galgano F, Labella R, Favati F (2015) Seed quality, oxidative stability and leaf metabolites of chia (Salvia hispanica L.) grown in southern Italy under different nitrogen fertilization. J Sci Food Agric in press

Ayerza R (1995) Oil content and fatty acid composition of chia (Salvia hispanica L.) from five northwestern locations in Argentina. J Am Oil Chem Soc 72:1079-1081

Ayerza R (2009) The seed's protein and oil content, fatty acid composition, and growing cycle length of a single genotype of chia (Salvia hispanica L.) as affected by environmental factors. $\mathrm{J}$ Oleo Sci 58(7):347-354

Ayerza R (2010) Effects of seed color and growing locations on fatty acid content and composition of two chia (Salvia hispanica L.) genotypes. J Am Oil Chem Soc 87(10):1161-1165

Ayerza R (2011) The seed's oil content and fatty acid composition of chia (Salvia hispanica L.) variety Iztac 1, grown under six tropical ecosystems conditions. Interciencia 8:620-624

Ayerza R (2013) Seed composition of two chia (Salvia hispanica L.) genotypes which differ in seed color. Emir J Food Agric 25(7):495-500. doi:10.9755/ejfa.v25i7.13569

Ayerza R, Coates W (1999) An omega-3 fatty acid enriched chia diet: its influence on egg fatty acid composition, cholesterol and oil content. Can J Anim Sci 1999(79):53-58

Ayerza R, Coates W (2000) Dietary levels of chia: influence on yolk cholesterol, lipid content and fatty acid composition for two strains of hens. Poult Sci 130(5):724-739

Ayerza R, Coates W (2001) Omega-3 enriched eggs: the influence of dietary a-linolenic fatty acid source on egg production and composition. Can J Anim Sci 81(3):355-362

Ayerza R, Coates W (2004) Protein and oil content, peroxide index and fatty acid composition of chia (Salvia hispanica L.) grown in six tropical and subtropical ecosystems of South America. Trop Sci 44(3):131-135

Ayerza R, Coates W (2005) Chia: rediscovering a forgotten crop of the Aztecs. The University of Arizona Press, Tucson, AZ

Ayerza R, Coates W (2006) Influence of Chia on total fat, cholesterol, and fatty acid profile of holstein cow's milk. RevistaCientifica de UCES (Universidad de CienciasEmpresariales y Sociales). , Volumen X (2), 40-49

Ayerza R, Coates W (2009a) Some quality components of four chia (Salvia hispanica L.) genotypes grown under tropical coastal desert ecosystem conditions. Asian J Plant Sci 8 (4):301-307

Ayerza R, Coates W (2009b) Influence of environment on growing period and yield, protein, oil and linolenic content of three chia (Salvia hispanica L.) selections. Ind Crop Prod 30:321-324

Ayerza R, Coates W (2011) Protein content, oil content and fatty acid profiles as potential criteria to determine the origin of commercially grown chia (Salvia hispanica L.). Ind Crop Prod 34:1366-1371

Ayerza R, Coates W, Lauria M (2002) Chia seed (Salvia hispanica L.) as an omega-3 fatty acid source for broilers: influence on fatty acid composition, cholesterol and fat content of white and dark meats, growth performance, and sensory characteristics. Poult Sci 81(6):826-837

Baginsky C, Arenas J, Escobar H, Garrido M, Valero D, Tello D, Pizarro L, Morales L, Silva H (2014). Determinación de fecha de siembraóptima de chia en zonas de clima desértico y templadomediterráneosemiáridobajocondiciones de riego en Chile. http://www.chia.uchile. cl/docs/anexos/Anexo_1.pdf

Bochicchio R, Rossi R, Labella R, Bitella G, Perniola M, Amato M (2015). Effect of sowing density and nitrogen top-dress fertilization on growth and yield of chia (Salvia hispanica L.) in a mediterranean environment. First results. Ital J Agron in press

Bresson JL, Flynn A, Heinonen M (2009) Opinion on the safety of chia seeds (Salvia hispanica L.) and ground whole chia seeds as a food ingredient. Eur Food Safety Authority J 996:1-26 
Bushway AA, Wilson AM, Houston L, Bushway RJ (1984) Selected properties of the lipid and protein fractions from chia seed. J Food Sci 49:555-557

Cabrera JC, Cerna MF (2014) Optimizaciòn de la aceptabilidad de un pan integral de chia (Salvia hispanica L.) mediante la metodologìa de Taguchi. Agroind Sci 4(1)

Cahill JP (2001) Domestication of chia, Salvia hispanica L.(Lamiaceae). Ph.D. thesis, University of California, Riverside, CA

Cahill JP (2003) Ethnobotany of chia, Salvia hispanica L. (Lamiaceae). Econ Bot 57:604-618

Cahill JP (2004) Genetic diversity among varieties of chia (Salvia hispanica L.). Genet Resour Crop Evol 51:773-781

Cahill JP (2005) Human selection and domestication of chia (Salvia hispanica L.). J Ethnobiol 25:155-174

Cahill JP, Ehdaie B (2005) Variation and heritability of seed mass in chia (Salvia hispanica L.). Genet Resour Crop Evol 52:201-207

Cahill JP, Provance MC (2002) Genetics of qualitative traits in domesticated chia (Salvia hispanica L.). J Hered 93(1):52-55

Capitani MI, Spotorno V, Nolasco SN, Tomás MC (2012) Physicochemical and functional characterization of by-products from chia (Salvia hispanica L.) seeds of Argentina. LWTFood Sci Technol 45:94-102

Capitani MI, Nolasco SM, Tomás MC (2013) Effect of mucilage extraction on the functional properties of Chia meals. In: Muzzalupo I (ed) Food Industry. InTech, Croacia. doi:10.5772/ 53171. http://www.intechopen.com/books/food-industry/effect-of-mucilage-extraction-onthe-functional-properties-of-chia-meals

Celli MG, Perotto MC, Martino JA, Flores CR, Conci VC, Pardina PR (2014) Detection and identification of the first viruses in chia (Salvia hispanica). Viruses 6(9):3450-3457

Coates W, Ayerza R (1996) Production potential of chia in northwestern Argentina. Ind Crop Prod $5(3): 229-233$

Coates W (2011) Whole and ground chia (Salvia hispanica L.) Seeds, chia oil—effects on plasma lipids and fatty acids. In: Patel VR, Preedy RR, Watson VB (ed) Nuts and seeds in health and disease prevention. Academic, San Diego, 309-314. doi:10.1016/B978-0-12-375688-6.10037-4

Coates W, Ayerza R (1998) Commercial production of chia in northwestern Argentina. J Am Oil Chem Soc 75(10): 1417-1420

De Kartzow A (2013) Estudio de Pre Factibilidad Técnico-Económica del Cultivo de Chía (Salvia hispánica L.) en Chile. FIA, Chile. http://www.fia.cl/Portals/0/UCP/Documentos/ Informe $\% 20$ Est $\% 20 \mathrm{Tec} \% 20 \mathrm{Econ} \% 20 \mathrm{de} \% 20 \mathrm{Chia} \% 20 \mathrm{en} \% 20 \mathrm{Chile.pdf}$

de la Paz Salgado-Cruz M, Calderón-Domínguez G, Chanona-Pérez J, Farrera-Rebollo Reynold R, Méndez-Méndez JV, Díaz-Ramírez M (2013) Chia (Salvia hispanica L.) seed mucilage release characterisation. A microstructural and image analysis study. Industrial Crops and Products 51:453-462

Dick M (2014) Desenvolvimento de FilmesBiodegradáveis a partir da Semente e da Mucilagem de Chia (Salvia hispanica L.). M.Sc. Dissertation, Universidade Federeal do Rio Grande do Sud, PortoAlegre. https://www.lume.ufrgs.br/bitstream/handle/10183/101486/000932289.pdf? Sequence $=1$

EFSA (2005) Opinion of the scientific panel on dietetic products, nutrition and allergies on a request from the commission related to the safety of chia (Salvia hispanica L.) seed and ground whole chia seed as a novel food ingredient intended for use in bread. EFSA J 278:1-12

EFSA (2009) Scientific opinion of the panel on dietetic products nutrition and allergies on a request from the European Commission on the safety of 'chia seed (Salvia hispanica) and ground whole chia seed' as a food ingredient. EFSA J 996:1-2

Gentry HS, Mittleman M, McCrohan PR (1990) Introduction of chia and gum tragacanth in the US. In: Advances in new crops. Proceedings of the first national symposium 'New crops: research, development, economics', Indianapolis, IN, USA, 23-26 October 1988. Timber, Portland, OR, pp. 252-256 
Hernández-Gómez JA, Miranda-Colín S (2008) Morphological characterization of chia (Salvia hispanica). Rev Fitotec Mex 31(2):105-113

Hernández-Gómez JA, Miranda-Colin S, Peña-Lonelí A (2008) Natural outcrossing of chia (Salvia hispanica L.). Revista Chapingo Serie Horticultura 14(3):331-337

Heuer B, Yaniv Z, Ravina I (2002) Effect of late salinization of chia (Salvia hispanica), stock (Matthiola tricuspidata) and evening primrose (Oenothera biennis) on their oil content and quality. Ind Crop Prod 15:163-167

Ixtaina VY, Nolasco SM, Tomas MC (2008) Physical properties of chia (Salvia hispanica L.) seeds. Ind Crop Prod 28(3):286-293

Ixtaina VY, Martínez ML, Spotorno V, Mateo CM, Maestri DM, Diehl BWK, Nolasco SM, Tómas MC (2011) Characterization of chia seed oils obtained by pressing and solvent extraction. J Food Comp Anal 24:166-174

Jamboonsri W (2010) Improvement of new oil crops for Kentucky. Doctoral dissertations, University of Kentucky, paper 120. http://uknowledge.uky.edu/gradschool_diss/120

Jamboonsri W, Phillips TD, Geneve RL, Cahill JP, Hildebrand DF (2012) Extending the range of an ancient crop, Salvia hispanica L. - a new $\omega 3$ source. Gen Res Crop Evol 59(2):171-178

Kroener E, Zarebanadkouki M, Kaestner A, Carminati A (2014) Non-equilibrium water dynamics in the rhizosphere: how mucilage affects water in soils. Water Resour Res 50(8):6479-6495

Lin KY, Daniel JR, Whistler RL (1994) Structure of chia seed polysaccharide exudate. Carbohydr Polym 23:13-18

Lobo Zavalia R, Alcocer MG, Fuentes FJ, Rodriguez WA, Morandini M, Devani MR (2011) Desarollo del cultivo de chia en Tucuman, Republica Argentina. EEAOC Adv Agroind 32 (4):27-30

Lu Y, Foo LY (2002) Polyphenolics of salvia. Phytochemistry 59:117-140

Marin Flores FM, Acevedo MJ, Tamez RM, Nevero MJ, Garay AL (2008) WO/ 2008/0044908 Method for obtaining mucilage from Salvia hispánica L. Word Internacional Property Organization 2008.

Marineli RS, Aguiar Morae E, Alves Leinquiste S, Teixeira Godoy A, Nogueira Eberlin M, Maróstica MR (2014) Chemical characterization and antioxidant potential of Chilean seeds and oil (Salvia hispanica L.). LWT_Food Sci Technol 59:1304-1310

Meineri G, Peiretti PG (2007) Apparent digestibility of mixed feed with increasing levels of chia (Salvia hispanica L.) seeds in rabbit diets. Ital J Anim Sci 6(1):778-780

Miranda-Colin S (1978) Evolucion de cultivaresnativos de Mexico. Ciencia y Desarrollo 3:130-131

Muñoz LA, Cobos A, Diaz O, Aguilera JM (2012a) Chia seeds: microstructure, mucilage extraction and hydration. J Food Eng 108:216-224

Muñoz JM, Aguilera Rodriguez-Turienzo L, Cobos A, Diaz O (2012b) Characterization and microstructure of films made from mucilage of Salvia hispanica and whey protein concentrate. J Food Eng 111(3):511-518

Muñoz LA, Cobos A, Diaz O, Aguilera JM (2013) Chia seed (Salvia hispanica): an ancient grain and a new functional food. Food Rev Int 29(4):394-408

Norlaily MA, Swee KY, Wan YH, Boon K, Sheau WT, Soon GT (2012) The promising future of chia, Salvia Hispanica L. J Biomed Biotechnol 2012(171956):1-9

Palma F, Donde M, Lloyd WR (1947) Fixed oils of Mexico. Part 1. Oil of chia_Salvia hispanica. J Am Oil Chem Soc 24:27

Pascual-Villalobos M, Correal E, Molina E, Martínez J (1997) Evaluación y Selección de Especies Vegetales Productoras de CompuestosNaturales con Actividad Insecticida. Centro de Investigación y DesarrolloAgroalimentario (CIDA), Murcia, Spain

Peiretti PG (2010) Ensilability characteristics of chia (Salvia hispanica L.) during its growth cycle and fermentation pattern of its silages affected by wilting degrees. Cub J Agric Sci 44(1):33-36

Peiretti PG, Gai F (2009) Fatty acid and nutritive quality of chia (Salvia hispanica L.) seeds and plant during growth. Anim Feed Sci Technol 148(2-4):267-275 
Peiretti PG, Meineri G (2008) Effects on growth performance, carcass characteristics, and the fat and meat fatty acid profile of rabbits fed diets with chia (Salvia hispanica L.) seed supplements. Meat Sci 80:1116-1121

Pizarro L, Lopes Almeida E, Sammán NC, Chang YK (2013) Evaluation of whole chia (Salvia hispanica L.) flour and hydrogenated vegetable fat in pound cake. LWT_Food Sci Technol 54 (1):73-79

Pozo Pozo SA (2010) Alternativas para el control químico de malezas anuales en el cultivo de la Chía (Salvia hispánica) en la granja ECAA, provincia de Imbabura, memoria de título. Ingeniero Agropecuario. Ibarra, Ecuador: Pontificia Universidad Católica del Ecuador, Facultad de ciencias agrícolas y ambientales E.C.A.A. Ibarra

Reyes-Caudillo E, Tecante A, Valdivia-López MA (2008) Dietary fibre content and antioxidant activity of phenolic compounds present in Mexican chia (Salvia hispanica L.) seeds. Food Chem 107:656-663

Rocha Uribe JA, Novelo-Perez JI, Castillo-Kauil H, Rosado-Rubio G, Alcocer CG (2011) Extraction of oil chia seeds with supercritical CO2. J Supercrit Fluids 56:174-178

Segura-Campos MR, Ciau-Solís N, Rosado-Rubio G, Chel-Guerrero L, Betancour-Ancona D (2014) Physicochemical characterization of chia (Salvia hispanica) seed oil from Yucatán, México. Agric Sci 5:220-226

Silveira Coelho M, de las Mercedes Salas-Mellado M (2014) Chemical characterization of Chia (Salvia hispanica L.) for use in food product. J Food Nutr Res 2(5):263-269

Silveira Coelho M, de las Mercedes Salas-Mellado M (2015) Effects of substituting chia (Salvia hispanica L.) flour or seeds for wheat flour on the quality of the bred. LWT-Food Sci Technol 60:729-736

Steffolani E, De La Hera E, Pèrez G, Gòmez M (2014) Effect of chia (Salvia hispanica L.) addition on the quality of gluten-free bread. J Food Qual 37:309-317, ISSN 1745-4557

Villegas D, Díaz V, Baginsky C, Silva H (2012) Efecto de la aplicación de herbicidas sobre el rendimiento en Chia (Salvia hispánica L.) en la Región Metropolitana. Poster of Departamento de ProducciónAgrícola, Facultad de Ciencias Agronómicas de la Universidad de Chile

Weber CW, Gentry HS, Kohlhepp EA, McCrohan PR (1991) The nutritional and chemical evaluation of chia seeds. Ecol Food Nutr 26:119-125

Yeboah S, Owusu Danquah E, Lamptey JNL, Mochiah MB, Lamptey S, Oteng-Darko P, Adama I, Appiah-Kubi Z, Agyeman K (2014) Influence of planting methods and density on performance of chia (Salvia hispanica) and its suitability as an oilseed plant. Agric Sci 2(4):14-26 